
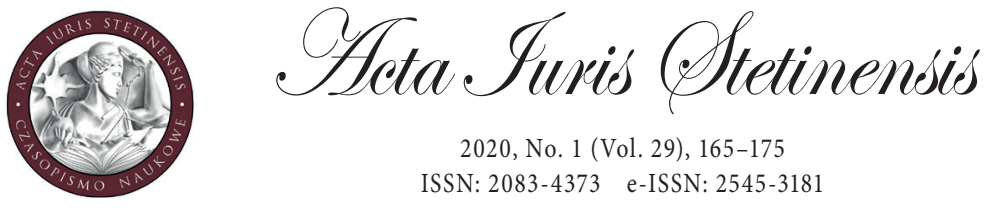

2020, No. 1 (Vol. 29), 165-175

ISSN: 2083-4373 e-ISSN: 2545-3181

DOI: $10.18276 /$ ais.2020.29-11

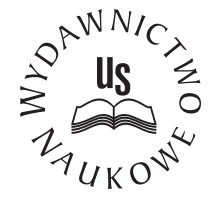

Jakub Tekielak

MA

Consultant in a tax consulting company, Poland

e-mail: jakub.tekielak@student.uj.edu.pl

ORCID ID: 0000-0001-6692-0115

\title{
Tax on revenue from buildings after the latest amendment: characteristics and doubts
}

\begin{abstract}
The aim of the article was to describe the current tax on revenue from buildings and to present the doubts connected with it. The author analysed legal acts, interpretations of the tax authorities, judgments of administrative courts, and views of tax law scholars and commentators for the article. The tax on revenue from buildings (until 2018 also known as the tax on commercial real estate) is a relatively new tax under Polish law. It was introduced in 2018, though it was amended considerably in 2019. Although it is regulated by the Personal Income Tax Act and the Corporate Income Tax Act, in fact it should be recognised as a kind of wealth tax. The taxpayers are the owners of buildings that are wholly or partially used for the purposes of tenancy, lease, and other similar contracts (the total value of the building has to exceed PLN 10 million). The tax rate is $0.035 \%$ of the building's value, paid monthly. It can be deducted from advance payments for income tax, and next it can be deducted from the income tax amount indicated in an annual tax return. The tax has created many doubts over interpretation. Some of them could be eliminated through the legislature's amendments to the relevant provisions.
\end{abstract}

Keywords: tax on revenue from buildings, personal income tax, corporate income tax 


\section{Introduction}

The income tax on commercial real estate (also known as the minimum income tax) was introduced into the Polish legal order by amendments to the Personal Income Tax Act ${ }^{1}$ (the PITA) and the Corporate Income Tax Act ${ }^{2}$ (the CITA), which were enacted in 2017. This tax came into force on 1 January 2018. Some of its features, however, raised doubts in the European Commission (in particular, over whether a narrower scope of taxation does not constitute a form of prohibited public aid in relation to entities using real estate of lower value, etc. ${ }^{3}$ ).

Therefore, the Polish government decided to amend the previous provisions through an amendment which was made under the Act of 15 June 2018, amending the PITA, the CITA, and the Lump Sum Income Tax on certain incomes earned by natural persons. ${ }^{4}$ Despite the retention from the previous wording of certain issues (such as the tax base or the level of the tax rate), the Act introduced some fundamental changes. The amendment came into force on 1 January 2019 at the beginning of the new financial year.

\section{Subject of taxation and entities taxed}

The tax on commercial real estate (since the amendment of 2018, which the legislature calls a tax on revenue from buildings) is regulated by Article $30 \mathrm{~g}$ of the PITA, and in a similar way with very minor differences in Article $24 \mathrm{~b}$ of the CITA. Originally, the object of taxation of this tax was the types of real estate enumerated in the Act, depending on the type of activity they were intended for (mainly related to trade and office space). The amendment of 2018 significantly changed the scope of taxation with this tax, in its new wording covering all buildings owned or co-owned by the a taxpayer that are wholly or partially used for tenancy, lease, or other similar contracts (they must be financial in nature, so this tax does not apply, for example,

1 Personal Income Tax Act, consolidated text: Dz.U. (Journal of Laws) of 2019, item 1387, as amended.

2 Corporate Income Tax Act, consolidated text: Dz.U. (Journal of Laws) of 2019, item 865, as amended.

3 Self-amendment to the governmental bill amending the Personal Income Tax Act, the Corporate Income Tax Act, and the Lump Sum Income Tax on certain incomes earned by natural persons Statement of reasons (https://www.sejm.gov.pl/Sejm8.nsf/druk.xsp?nr=2291-A).

4 Act of 15 June 2018 amending the PITA, the CITA, and the Lump Sum Income Tax on certain incomes earned by natural persons, Dz.U. (Journal of Laws) of 2018, item 1291. 
to contracts regarding use $\mathrm{e}^{5}$ or lending free of charge). Thus, the list of items subject to the tax has been narrowed down (at least as regards buildings which were already subject to taxation before the amendment came into force), because if a building or part of it is not leased, etc., it is no longer subject to the tax. On the other hand, in some respects, the scope of the entities has expanded, as there is no longer any limitation on the types of buildings to be taxed. In contrast to the previous version, it includes warehouses and - in certain situations - even residential buildings, among others. ${ }^{6}$ Taxation concerns owners and co-owners of buildings located in the Republic of Poland. However, by way of exception, pursuant to Art. 30g(17) of the PITA and Art. 24b(17) of the CITA, if the building in question is the object of a financial leasing agreement and the conditions for its taxation with the tax in question are met, a lessee who claims deductions for depreciation of the building is the taxpayer, instead of the owner. ${ }^{7}$ Moreover, in the case of personal income tax, there is an additional premise: the object of taxation must be an asset related to business activity. This means that the obligation to pay tax on revenue from buildings shall not apply to natural persons obtaining revenue from the 'private lease's referred to in Article 1(2) of the Lump Sum Income Tax Act. ${ }^{9}$

In addition, in the latest amendment of 2018 (in effect since 1 January 2019), the legislature in Article $30 \mathrm{~g}(18)$ of the PITA and in Article 24b(18) of the CITA included a provision preventing avoidance of tax on revenue from buildings by transferring ownership (or co-ownership) of a given building asset to another person, or by putting it into use through a financial leasing agreement (according to tax law). The legislation requires that a taxpayer who has thus disposed of the real estate in question must remain liable to taxation under two conditions: firstly, that the taxpayer, in carrying out the transaction, tried to avoid being subject to the tax in question, and secondly, that the transaction had no legitimate economic reasons. The tax authority then has the power to determine the tax liability of the original owner (co-owner) of the building, which in turn results in no tax liability for

5 Individual interpretation of the Director of the National Revenue Information System of 20.02.2019, ref. no. 0111-KDIB1-3.4010.163.2019.1.MBD (sip.mf.gov.pl).

6 Banasik, P. et al., Podatek od przychodów z budynków - następca minimalnego podatku dochodowego od wartości budynków komercyjnych - wybrane problemy, "Przegląd Podatkowy" 2018, No. 2, LEX.

7 Sender, E., Jak liczyć podatek od przychodów z budynku?, 29.05.2019, Rzeczpospolita, https:// www.rp.pl/Podatek-dochodowy/305299993-Jak-liczyc-podatek-od-przychodow-z-budynku.html (accessed 22.04.2020).

8 Jankowski, J., Zmiany w minimalnym podatku od nieruchomości komercyjnych w 2019 r., "Nieruchomości” 2019, No. 1, Legalis.

9 Lump Sum Income Tax Act, consolidated text: Dz.U. (Journal of Laws) of 2019, item 43, as amended. 
the buyer of the property. These regulations constitute a special clause against tax avoidance for the purposes of the tax under study.

The PITA and the CITA do not contain a definition of a building. Therefore, the question arises as to how a building should be interpreted in terms of the tax on revenue from buildings. It seems that the most accurate method would be to refer to the Classification of Fixed Assets (the CFA), which in the case of income tax is also the basis for selecting the depreciation rate of a fixed asset. The scope of entities subject to the tax on revenue from buildings has already been the subject of many tax interpretations. For example, in the individual interpretation of 24 May 2019, ref. no. 0114-KDIP2-1.4010.153.2019.1.JC, ${ }^{10}$ the Director of the National Revenue Information System considered that a stadium is not subject to tax on revenue from buildings, because in the CFA stadiums are classified under Group 290 as 'Sport and recreational buildings' and not as buildings. This interpretation confirms the thesis that in order to define whether a given structure is subject to the tax on revenue from buildings, it should be considered how the object is qualified in the CFA.

The question also arises whether the objects of taxation - buildings - are fixed assets, since under the provision of Article $30 \mathrm{~g}(1)$ of the PITA (and, accordingly, Article $24 \mathrm{~b}$ (1) of the CITA), such fixed assets include only buildings in which premises have not been separated or buildings in which premises have been separated but with a share in a common area. This issue was also the subject of one of the individual interpretations of the director of the National Revenue Information System. In this interpretation, the director agreed with the taxpayer's position (the owner of a building in which premises have not been separated or of premises in other buildings which share a common area and form a housing community) that

"Although in Article 30g of the PITA the legislature also uses the notion of coownership of the building (indicating in Article $30 \mathrm{~g}(5)$ of the PITA the method for calculating the initial value for the purpose of calculating the tax), it does not in any way refer to the minimum tax for premises separated within a given building. (...) Moreover, the Classification of Fixed Assets, indicating fixed assets that are real estate, treats buildings and premises separately. In addition, the definitions of building and premises contained in the explanatory notes to the above-mentioned Classification are not the same, which clearly demonstrates the need to distinguish between them". 11

10 Individual interpretation of the Director of the National Revenue Information System of 24 May 2019, ref. no. 0114-KDIP2-1.4010.153.2019.1.JC (sip.mf.gov.pl).

11 Individual interpretation of the director of the National Revenue Information System of 18 February 2019, ref. no. 0115-KDIT3.4011.537.2018.2.WM (sip.mf.gov.pl). 
Furthermore, it would therefore follow from the position presented above that if the owner of a building separates premises within it on the basis of the Act on the Ownership of Premises ${ }^{12}$ and makes himself the owner of such premises, then he is not liable for the tax on revenue from buildings. A similar situation may occur if a taxpayer decides to separate the premises and transfer ownership of them to another person, e.g., a family member, in order to limit taxation. Interestingly, the special circumvention clause included in Article $30 \mathrm{~g}(18)$ of the PITA (and, accordingly, Article $24 \mathrm{~b}(18)$ of the CITA), added as a result of the 2018 amendment, would not apply to such a taxpayer. ${ }^{13}$ This is due to the fact that, according to the above-mentioned provisions, this clause applies only to an economically unjustified transfer of all or part of the ownership or co-ownership of a building or making the building available under a financial leasing agreement (according to the tax law). In such a case, the clause may not be effective, because it does not include an economically unjustified separation of the premises. Of course, this does not change the fact that the example of optimisation presented above, provided certain conditions are met, could still be challenged on the basis of the general anti-avoidance clause referred to in Article 119a of the Tax Ordinance. ${ }^{14}$ The example was intended to identify certain loopholes in the special clause for the tax on revenue from buildings, which may reduce its effectiveness to some extent.

Importantly, the legislature decided to introduce several exemptions to the taxation of buildings. One of them is provided for in Article $30 \mathrm{~g}(2)$ of the PITA and Article $24 \mathrm{~b}(2)$ of the CITA, by exempting from the tax the revenue from a fixed asset which is a residential building put into use due to the implementation of government and self-government social housing programmes if this exemption constitutes compensation that meets the conditions laid down in Commission Decision 2012/21/EU of 20 December 2011 on the application of Article 106(2) of the Treaty on the functioning of the European Union to state aid in the form of public service compensation granted to certain undertakings entrusted with the operation of services of general economic interest (OJ L 7, 11.1.2012, p. 3).

A similar rule also applies when not the entire building, but part of its premises (area) has been put into operation within the implementation of government and self-government programmes for social housing (Article 30g(8) of PITA and Article $24 \mathrm{~b}(8)$ of CITA). Then, the revenue should be reduced according to the

12 Act on the ownership of premises, consolidated text: Dz.U. (Journal of Laws) of 2020, item 532, as amended.

13 Bauta-Szostak, J. and Kran, R., Opodatkowanie nieruchomości w działalności gospodarczej. Podatek od nieruchomości. Podatek od przychodów z budynków, Warszawa 2018, p. 372.

14 Tax Ordinance Act, consolidated text: Dz.U. (Journal of Laws) of 2019, item 900, as amended. 
proportion of such premises in the usable area of the building. In addition, in accordance with Article $30 \mathrm{~g}(7)$ of the PITA (and by analogy, according to Article $24 \mathrm{~b}$ (7) of the CITA), buildings whose useful floor area has been put into use, i.e. for the purposes of tenancy, lease, etc. does not exceed $5 \%$ of the total area of the building are exempted from the tax.

\section{Tax rate and method of payment}

The legislature's inclusion of the discussed provisions in the income tax acts is an unprecedented measure in Polish tax law, since the tax on revenue from buildings is in fact a wealth tax (in its original version prior to the amendment as well). A wealth tax is to be understood as 'a tax whose source is the taxpayer's wealth.' ${ }^{15}$ The tax base for this tax is the sum of revenues, though the use of the word 'revenue' is only a legal fiction and does not refer to revenue as a monetary or non-monetary benefit, as it is understood in Polish income tax law. This fiction results from the fact that, pursuant to Art. $30 \mathrm{~g}$ (3) of the PITA and Art. $24 \mathrm{~b}$ (3) of the CITA, for the purposes of tax on revenue from buildings, the revenue is, by definition, understood as 'the initial value of the taxable fixed asset resulting from records, determined on the first day of each month, and in the month in which the fixed asset was entered in the records, the initial value determined on the day the fixed asset was entered into the evidence.'

It is clear that this is completely different from the understanding of revenue in Polish income tax law. Clearly, the tax base (the so-called revenue) here is the value of a specific asset in the form of the sum of the value of buildings belonging to a given tax entity. Consequently, this tax should be qualified as a wealth tax, despite the misleading term 'revenue' in the regulations in question. It is therefore interesting that the legislature decided to introduce such a tax not in a separate act but using the income tax laws, which by definition do not refer to wealth as such. It is likely that the inclusion of these provisions in income tax law was forced by the fact that they are intended to have a sealing effect, in particular with regard to income taxes. Apart from that, the second reason for this is the fact that the tax on revenue from buildings, if certain conditions are met, may be deducted from advances on income tax (this will be discussed in detail below). In itself, the way the tax is calculated is highly original, which is the result of the purposes for which it was established. Above all, the idea of its introduction was based on the view that many entities from the commercial real estate sector use tax optimization which

15 Gomułowicz, A. and Mączyński, D., Podatki i prawo podatkowe, Warszawa 2016, p. 164. 
allows them to pay extremely low taxes in Poland. ${ }^{16}$ The legislature, guided by this conviction, decided that an entrepreneur should pay some minimal income tax when using wealth of high value. The tax under analysis is correlated to the value of the taxpayer's wealth, and the taxpayer bears a financial burden from it only if the taxpayer does not achieve adequate income subject to income tax. ${ }^{17}$

The monthly tax base is always calculated by deducting an amount of PLN 10 million from the sum of the value of the buildings belonging to a given taxpayer (Article $30 \mathrm{~g}(9)$ of the PITA and, similarly, Article $24 \mathrm{~b}(9)$ of the CITA). Thus, we can say that PLN 10 million is an allowance, a tax-free amount (or rather a tax-free value). Therefore, only the excess value above this amount is subject to taxation. ${ }^{18}$ As a result, owners of buildings whose value does not exceed PLN 10 million are exempted from the tax. The tax rate has not changed as a result of the amendment and is still $0.035 \%$ of the tax base per month.

Looking at the above-mentioned features of the tax on revenue from buildings, the thesis that it is, to some extent, a kind of ad valorem tax (according to value) on real estate seems to be correct, but with a significantly limited scope of the object of taxation. Moreover, unlike the ad valorem tax in its classic version, i.e. the one in force in Germany and Spain, ${ }^{19}$ it is not based on the 'real estate cadastre'. As mentioned above, the tax in question is calculated on the basis of the value of the building, resulting from the fixed assets evidence of the taxpayer and it is related to the initial value of the building, i.e. also adopted for depreciation purposes. In accordance with Article $30 \mathrm{~g}(6)$ of the PITA (and analogously Article $24 \mathrm{~b}(6)$ of the CITA), if only part of a building is put into use (putting into use means using for the purposes of tenancy, etc. ${ }^{20}$ ), then the revenue is determined by calculating the proportion of the area put into use to the total area of the building. It is also worth noting that in the CITA (Article 24c) the legislature provided for a regulation concerning the rules of determining the tax on revenue from buildings within a tax capital group. It follows that in the case of commercial real estate tax as well, companies belonging to a tax capital group are treated as one taxpayer.

However, the question arises as to whether it should be the full initial value of the building that is taken into account for the purposes of the tax on revenue from

16 Banasik P., et al., op. cit.

17 Ibidem.

18 Małecki, P. and Mazurkiewicz, M., Komentarz do art.24(b) ustawy o podatku dochodowym od osób prawnych, in: Małecki, P. and Mazurkiewicz, M. (eds.), CIT. Komentarz. Podatki i rachunkowość, Warszawa 2018 (LEX).

19 Firlej, K.A. and Firlej, C., Porównanie systemów opodatkowania nieruchomości w Unii Europejskiej, "Progress in Economic Sciences" 2014, No. 1, p. 295.

20 Banasik, P., et al., op. cit. 
buildings or the current value, i.e. taking into account depreciation write-offs made before the first day of a given month or possible improvements within the meaning of Article 22g(13) of the PITA (and Article $16 \mathrm{~g}(13)$ of the CITA), which seems to be suggested by Article $30 \mathrm{~g}$ (3) of the PITA (and Article $24 \mathrm{~b}$ (3) of the CITA) using the following words: "The revenue referred to in Paragraph 1 shall be the initial value calculated on the first day of each month." This problem has become the subject of an individual interpretation issued by the director of the National Revenue Information System, ${ }^{21}$ in which it was considered that the initial value should be adopted for tax purposes, without any updates related to the deduction of previous depreciation deductions. The claimant challenged this interpretation to the Voivodship Administrative Court (VAC) in Warsaw (not the final judgment), ${ }^{22}$ which accepted the claimant's position and repealed the challenged interpretation. The Court considered that only the undepreciated part of the initial value should be used for tax calculation purposes. In solving the problem, the Court referred to the principle of resolving doubts in favour of the taxpayer ${ }^{23}$ (Article 2a of the Tax Ordinance). The judgment appears to be a fair compromise, since the provision which the contested interpretation is about is imperfectly worded and raises fundamental doubts in this respect. The VAC in Warsaw ruled again in a similar spirit on 22 May 2019. ${ }^{24}$ This ruling is also not final. Although these judgements were based on provisions which were valid prior to 1 January 2019, they can still be taken as a reference, since both provisions - before and after this date - related to the calculation of the tax base are almost the same (only the wording has been changed, but doubts remained).

In practice, however, many entities still take a cautious approach to this issue, taking the full initial value as the tax base, i.e. without any deductions for depreciation. This is particularly due to the individual interpretations of the tax law made by the director of the National Revenue Information System, ${ }^{25}$ despite the existence of judgments challenging this point of view. The unfavourable line of interpretation is

21 Individual interpretation of the Director of the National Revenue Information System of 30 May 2018, ref. no. 0114-KDIP2-1.4010.83.2018.1.JC (sip.mf.gov.pl).

22 Judgment of the Voivodship Administrative Court in Warszawa of 17 April 2019, III SA/Wa 1905/18 (source: jud.nsa.gov.pl).

23 Zalewski, Ł., Precedensowy wyrok WSA: Podatek od przychodów z budynków można obniżać, 09.05.2019, Dziennik Gazeta Prawna, https://podatki.gazetaprawna.pl/artykuly/1411365,jak-obnizyc-podatek-od-nieruchomosci.html (accessed 22.04.2020).

24 Judgment of the Voivodship Administrative Court in Warszawa of 22 May 2019, III SA/Wa 1903/18 (jud.nsa.gov.pl).

25 Individual interpretation of the Director of National Revenue Information System of 9 March 2020, ref. no. 0111-KDIB2-1.4010.8.2020.1.EN; Individual interpretation of the Director of National Revenue Information System of 5 February 2020, ref. no. 0114-KDIP2-1.4010.518.2019.1.JF (sip.mf.gov.pl). 
probably maintained due to the fact that at the moment of writing this article, these judgments are still non-final, as the director of the National Revenue Information System has lodged a cassation complaint against them. Therefore, a postulate should be made for the legislature itself to solve this problem of interpretation, making the provisions more precise in this respect.

In the case of both the PITA and the CITA, the procedure for paying the tax is remarkably similar. The mechanism adopted in accordance with Article $30 \mathrm{~g}(11)$ of the PITA (and, similarly, Article 24b(11) of the CITA) sets the deadline for payment of the tax at the twentieth day of each month (however, in the case of payment of the tax for the last month of the tax year, it must be paid by the deadline for submitting the annual tax return). Then, the tax paid on revenue from buildings is deducted from the advance payment for income tax. This applies to both personal income tax and corporate income tax (however, in the case of personal income tax, this applies only to advances on income from business activities). In case the amount of tax on revenue from buildings turns out to be lower than the amount of advance payment of income tax for a given month, the taxpayer is entitled not to pay tax on revenue from buildings for the month. The full amount of tax on revenues from buildings paid during the tax year is deducted by the taxpayer from the tax calculated after the end of the tax year. Article $30 \mathrm{~g}(15)$ of the PITA and Article $24 \mathrm{~b}(15)$ of the CITA provide for a special refund procedure. It covers entities which did not have the possibility to fully deduct the amount of the tax on revenue from buildings from the income tax in their annual return (e.g. due to a loss or low income tax to be paid, i.e. lower than the value of the tax on revenue from buildings). This is a different procedure to the refund of an overpayment of a specific nature, as referred to in Article 75 of the Tax Ordinance. ${ }^{26}$ In principle, the refund of the tax on revenue from buildings is to 'be granted to these taxpayers whose loss or low income tax does not result from the tax optimisations applied, ${ }^{27}$ and is only made at the request of the taxpayer. However, the tax authority will be able to challenge the refund if it considers that other revenues and expenses have been determined on non-market terms. On the other hand, pursuant to Article $30 \mathrm{~g}(16)$ of the PITA and Article 24b(16) of the CITA, if the tax authority determines the tax liability or loss to be a different amount than that resulting from the tax return, the taxpayer is entitled to a refund of tax on revenue from buildings equivalent to the difference between the amount of paid and non-deducted tax on revenue from

26 Szulc, M., Podatek galeryjny wycieknie $z$ deklaracji? Pieniadze moga przeciec fiskusowi przez palce, 4.02.2019, Gazeta Prawna, https://podatki.gazetaprawna.pl/artykuly/1395809,pieniadze-zpodatku-minimalnego-moga-przeciec-fiskusowi-przez-palce.html (accessed 22.04.2020). 
buildings and the amount of tax determined by the tax authority (in the case of calculating tax liability) or equivalent to the paid and non-deducted tax on revenue from buildings (in the case of losses being calculated by the authority). This refund solution model entered into force in 2019.

\section{Conclusion}

The tax on revenue from buildings is a new levy, existing since 2018. Although it has been in effect a short time, it has already been thoroughly amended once. Despite having the characteristics of a wealth tax, the legislature decided to qualify it as an income tax. Thus, it was introduced to the income tax laws for natural persons and for corporate entities. In both acts it takes virtually the same form. The entities that are subject to this tax are the owners and co-owners of the buildings. However, it does not cover owners of separated premises, which was confirmed by the director of the National Revenue Information System in one of the individual interpretations. The object of the tax is buildings intended to be used for rental, lease, and other similar agreements. The tax base is the value of the building resulting from the taxpayer's evidence reduced by PLN 10 million. The tax is paid monthly and amounts to $0.035 \%$ of the tax base. The tax paid on revenue from buildings is deducted from advances on income tax and then from income tax.

The tax on revenue from buildings was created to a large extent in order to curb tax optimisation ${ }^{28}$ and to increase the state budget revenues from economic activity related to large-area trade and renting of office space. However, in view of the European Commission's doubts, it has been decided to change the scope of the tax so that it can now also cover buildings used for other sectors of business. Following the amendment of the acts, certain provisions of the tax law still raise questions relating to the proper interpretation, including fairly important issues (e.g. what value should be used when calculating the tax base). Therefore, a de lege ferenda postulate should be made, proposing clarification of the most important doubts by unifying the provisions that cause the greatest problems in interpretation.

28 Draft Act amending the Personal Income Tax Act, the Corporate Income Tax Act, and the Lump Sum Income Tax Act on certain incomes earned by natural persons, Statement of reasons, p. 23 (https://legislacja.rcl.gov.pl/projekt/12300402/katalog/12445416\#12445416). 


\section{References}

Banasik, P., et al., Podatek od przychodów z budynków - następca minimalnego podatku dochodowego od wartości budynków komercyjnych - wybrane problemy, "Przegląd Podatkowy" 2018, No. 2, LEX.

Bauta-Szostak, J. and Kran, R., Opodatkowanie nieruchomości w działalności gospodarczej. Podatek od nieruchomości. Podatek od przychodów z budynków, Warszawa 2018.

Firlej, K.A. and Firlej, C., Porównanie systemów opodatkowania nieruchomości w Unii Europejskiej, "Progress in Economic Sciences" 2014, No. 1.

Gomułowicz, A. and Mączyński, D., Podatki i prawo podatkowe, Warszawa 2016.

Jankowski, J., Zmiany w minimalnym podatku od nieruchomości komercyjnych w 2019 r., "Nieruchomości" 2019, No. 1, Legalis.

Małecki, P. and Mazurkiewicz, M., Komentarz do art.24(b) ustawy o podatku dochodowym od osób prawnych, in: Małecki, P. and Mazurkiewicz, M. (eds.), CIT. Komentarz. Podatki i rachunkowość, Warszawa 2018, LEX.

Sender, E., Jak liczyć podatek od przychodów z budynku?, 29.05.2019, Rzeczpospolita, https://www.rp.pl/Podatek-dochodowy/305299993-Jak-liczyc-podatek-od-przychodow-z-budynku.html.

Szulc, M., Podatek galeryjny wycieknie $z$ deklaracji? Pieniaddze moga przeciec fiskusowi przez palce, 4.02.2019, Gazeta Prawna, https://podatki.gazetaprawna.pl/artykuly/1395809,pieniadze-z-podatku-minimalnego-moga-przeciec-fiskusowi-przez-palce. html.

Zalewski, Ł., Precedensowy wyrok WSA: Podatek od przychodów z budynków można obniżać, 9.05.2019, Dziennik Gazeta Prawna, https://podatki.gazetaprawna.pl/artykuly /1411365,jak-obnizyc-podatek-od-nieruchomosci.html.

\section{CITATION}

TEKIELAK, J., Tax on revenue from buildings after the latest amendment: characteristics and doubts, "Acta Iuris Stetinensis" 2020, No. 1 (Vol. 29), 165-175, DOI: 10.18276/ais.2020.29-11. 